\title{
Mortality Decline by Cause in Urban and Rural England and Wales, 1851-1910
}

\author{
Andrew Hinde \\ Southampton Statistical Sciences Research Institute \\ University of Southampton \\ Bernard Harris \\ School of Social Work and Social Policy \\ University of Strathclyde
}

\section{Address for correspondence}

Andrew Hinde, Department of Social Statistics and Demography, University of Southampton SOUTHAMPTON SO17 1BJ, United Kingdom. Andrew.Hinde@soton.ac.uk

Version. 9.4 (13 March 2019). Text: 11,177 words (including footnotes and references).

Short title. Mortality decline in England and Wales

Mortality decline by cause/Title/ 1 


\section{Acknowledgements}

Earlier versions of this paper were presented at the European Society for Historical Demography Conference in Leuven, Belgium, 21-24 September 2016, the Social Science History Association Conference in Chicago, United States, 17-20 November 2016, and an Historical Economics Development Group Workshop on 'Public interventions, health and population in history' held at in Odense on 15 June 2017. We are grateful to the participants at those meetings for comments, and especially Jonathan Chapman and Joe Ferrie. Assistance with data preparation was provided by Jamal Abdul Nasir and Joel Hinde. The insightful comments of several referees have help us re-shape and focus the paper. 


\title{
Mortality Decline by Cause in Urban and Rural England and Wales, 1851-1910
}

\begin{abstract}
This paper presents a new analysis of the contribution of particular causes of death to the decline of mortality in England and Wales between 1851 and 1910. We examine deaths in a set of 588 registration areas based on the registration districts but amalgamated where necessary so that the boundaries of the areas are consistent over time. The deaths are classified by cause, and the paper discusses changes in the classification of causes of death between 1851 and 1910 and attempts to use as congruent a set of classes as is possible. The results show that declines in deaths from waterborne diseases and scarlet fever had their greatest impact between the 1860s and the 1880s, pulmonary tuberculosis declined steadily throughout the period, and diseases of the lungs were important between the 1890s and 1901-1910. The paper then examines causespecific death rates in urban and rural areas, using definitions of 'urban' based on both population density and settlement size. The results are largely insensitive to the definition of what constitutes an urban area. They reveal that mortality from typhus/typhoid and pulmonary tuberculosis declined in parallel in urban and rural areas. Mortality from scarlet fever converged to very low levels in all areas by 1901-1910. There were, however, differences between town and countryside in the pace and timing of the decline of mortality from diarrhoeal diseases. Where there were differences, it was often the smaller urban areas that stood apart: there was no gradation from rural areas through small towns to larger towns. The paper concludes with some remarks on the implications of our findings for the role of public investment in mortality decline.
\end{abstract}

Keywords. Mortality decline, urban areas, rural areas, cause of death, England and Wales Mortality decline by cause/Abstract/ 1 


\section{Mortality Decline by Cause in Urban and Rural England and Wales, 1851-1910}

\section{Introduction}

The second half of the nineteenth century witnessed substantial improvements in the mortality experience of the people of England and Wales. The decline of mortality began among those aged 5-9 years in the late 1840 s and early 1850 s, before spreading to older age groups. These improvements enabled average life expectancy at birth to improve by approximately 12 years between the mid nineteenth century and 1914 (Harris and Hinde, 2019).

The reasons for these improvements continue to provoke debate. Thomas McKeown (1976) distinguished between water- and food-borne infections and airborne infections. He argued that the former accounted for approximately 33 per cent of the overall decline in mortality between 1848-1854 and 1901, and that the latter accounted for approximately 44 per cent of the overall decline. (He attributed 15 per cent of the overall decline to other infectious diseases and approximately 8 per cent to non-infectious causes.) He also claimed that the relative importance of the decline in mortality from airborne infections demonstrated that the primary underlying cause of mortality decline was an improvement in diet and the standard of living, a claim which has been subject to a sustained critique over the last four decades.

As we show in the next section, the debate over the causes of mortality decline is directly connected to concerns over the impact of urbanisation. It is widely accepted that urban areas in England and Wales were extremely unhealthy places during the nineteenth century (Beach and Hanlon, 2018, p. 2,652), and much less healthy than rural areas. Since the proportion of the population living under urban conditions increased rapidly over the course of this period (Bennett, 2012), the fact that life expectancy improved in the face of rapid urbanisation is 
especially noteworthy. It has been argued that a reason for this was that public investment in sanitation and other improvements to the urban environment reduced the extent of the 'urban penalty', which offset the effect of the higher proportion of the population living in towns and cities. $^{1}$

This paper aims to shed new light on both the contribution of different causes of death to the mortality decline and the impact of urbanisation. We begin by revisiting some of the 'classic' arguments about mortality change during this period. We then proceed to summarise the main changes in cause-specific mortality using the Registrar-General's Decennial Supplements for the period 1851-1860 to 1901-1910. We use the method devised by BeltránSánchez et al. (2008) to re-estimate the contributions made by different causes of death to the overall process of mortality decline. We then use the information derived from this exercise to examine changes in mortality from different diseases in both urban and rural areas. Finally, we make some comments about the implications of our results for the argument that public investment was crucial to the decline of urban mortality.

\section{Revisiting mortality decline}

As we have already suggested, there is a long tradition of seeking to understand the process by focusing on 'diseases which declined' (recent contributions to this line of research include Mercer, 2014; and Mooney, 2015). As McKeown and Record (1962, pp. 33-4) acknowledged,

\footnotetext{
${ }^{1}$ A reduction in the 'urban penalty' is, of course, not necessary for overall mortality to decline even when the population is redistributing itself to less healthy environments. Mortality could decline in parallel in both urban and rural areas and, provided the decline is great enough, overall mortality will still fall. However a reduction in the 'urban penalty' allows overall mortality to decline even though the decline in mortality in rural areas is more modest.
}

Mortality decline by cause/Text/ 2 
this is a rather fraught undertaking because of the problems associated with the uncertain diagnosis of causes of death during the period under review. However, this did not stop them from drawing some bold conclusions from the analysis they were able to undertake. They argued that the most important 'contributors' to the decline of mortality were tuberculosis; typhus, enteric fever and simple continued fever; scarlet fever; diarrhoea, dysentery and cholera; smallpox; and whooping cough (McKeown and Record, 1962, p. 35). McKeown revisited this analysis, using a slightly different set of data, in 1976 but his overall conclusions were largely unchanged (McKeown, 1976, pp. 50-64).

McKeown's arguments were subjected to a wide-ranging critique by Simon Szreter. Szreter (1988) argued that McKeown had overestimated the relative importance of tuberculosis in particular and airborne infections in general, and that this had led him to underestimate the significance of improvements in the number of deaths associated with water- and food-borne infections. As a result, he also argued that McKeown had underestimated the impact of the sanitary initiatives associated with these diseases. Although his critique has itself been challenged (see, for example, Guha, 1994), it continues to attract widespread attention.

Woods (2000) provided a much fuller account of the history of mortality decline. He revisited McKeown and Record's original analysis using a newly-computerised version of the Registrar General's Decennial Supplements, but the overall picture was not radically different from the picture painted by McKeown and Record four decades earlier. His most important contribution was to provide a much more fine-grained geographical analysis of the process of mortality decline in different areas. Woods was broadly sympathetic to McKeown's view that the most important direct contribution to mortality decline was associated with the decline of mortality from tuberculosis, but found little evidence to support McKeown's claim that the main 
underlying cause of the decline in tuberculosis mortality was an improvement in the quality and quantity of the nation's diet. He argued that it was the result of an autonomous decline in the virulence of the infection itself (Woods, 2000, pp. 358-9), but was unable to provide any direct evidence to support this contention, and many remained unconvinced (see, for example, Harris, 2004, p. 399). Woods was also sympathetic to Szreter's focus on the role of sanitary intervention, although he also warned against what he called 'simple conclusions' (Woods, 2000, pp. 357-8).

Woods' work raised the study of mortality decline to a new level of geographicallyinfused sophistication but also generated questions of its own. His analysis of the decline of mortality from water- and food-borne diseases has provoked controversy. Woods argued that the decline of mortality from diarrhoea and typhus was linked to specific areas and, although he did not provide any direct evidence, he concluded that this demonstrated the importance of geographically-specific sanitary initiatives (Woods, 2000, pp. 354-8). However, as Harris and Hinde (2019) have pointed out, Woods' treatment of diarrhoea and typhus is somewhat perplexing, given that typhus was a louse-borne infection which was only distinguished from typhoid at the end of the 1860s. They also demonstrated that much of the decline in mortality from these diseases occurred towards the start of Woods' period, and that some of the improvements appeared to predate substantial increases in sanitary spending.

This paper provides some new data and analysis of the decline of mortality by cause in England and Wales across the six decades 1851-1860 to 1901-1910. The analysis relies on the consistency of the cause of death categories used in each decade, which cannot be assured from the data, as the Register General made changes to the classification scheme used to report deaths by cause, especially in 1901. We discuss these changes and develop a consistent classification 
scheme that identifies those causes of death deemed by previous researchers to have been most important.

We then consider the evolution of cause-specific death rates in urban and rural areas, using two different definitions of what constitutes an urban area. This analysis is based on a data set of deaths and death rates by cause for a set of 588 geographical areas, created to have largely consistent boundaries over the six decades. This set of areas is based on the registration districts of England and Wales, but amalgamates registration districts which were abolished or created during the period, or which were involved in substantial boundary changes.

The distinction between urban and rural areas is an important one in the context of the issues raised earlier. As we have already seen, it is generally accepted that, at the start of our period, urban areas were generally less healthy than rural areas. It is also clear that these areas enjoyed the lion's share of sanitary investment, certainly after 1870 (Harris and Hinde, 2019, p. 4). If, as McKeown (1976, p. 159) argued, these investments were most likely to have an effect on mortality from waterborne diseases, one might therefore expect to see a disproportionate decline in the incidence of mortality from these diseases in urban areas.

\section{Mortality decline by cause of death}

A decomposition of the decline of mortality by causes of death was central to the arguments of McKeown and his colleagues (see, for example, McKeown and Record 1962, p.104). Woods (2000, pp. 346-53) used cause-deleted life tables and age-standardised numbers of deaths from particular causes to examine changes in mortality between the $1860 \mathrm{~s}$ and the $1890 \mathrm{~s}$. He showed 
that the three biggest contributors to mortality decline were diarrhoea and typhus (which he combined into a single category), scarlet fever, and pulmonary tuberculosis (or phthisis). ${ }^{2}$

In this paper we extend the analysis in two ways. First, we use a relatively new method (Beltrán-Sánchez et al., 2008) to examine the contribution of different causes of death to changes in mortality over time. Second, we evaluate the contribution of each cause of death over the six decades from 1851-1860 to 1901-1910, rather than the three decades 1861-1870 to 1891-1900.

The method of Beltrán-Sánchez et al. (2008) builds on the idea of cause-deleted life tables to allow the decomposition of changes in the expectation of life between any two periods by cause of death. Consider a particular cause of death, $i$. If age specific death rates (ASDRs) from cause $i$ change over time this will have two effects on the expectation of life at birth. The first effect derives directly from changes in the ASDRs from cause $i$. We can refer to this as the direct effect of changes in mortality from cause $i$ on the expectation of life at birth. Second, the change in the ASDRs from cause $i$ will have an impact on ASDRs for all other causes. For example, if ASDRs from cause $i$ fall relative to ASDRs from other causes, people who formerly died of cause $i$ will die from one of the other causes, and this will increase mortality from those causes. We can call this the indirect effect of changes in mortality from cause $i$. Of course, changes in the ASDRs from other causes of death will also indirectly affect mortality from cause $i$. The overall impact on the expectation of life at birth of change in mortality from any cause will be the sum of both these effects. The method of Beltrán-Sánchez et al. (2008) computes both the direct and indirect effects on the expectation of life at birth of changes in the ASDRs from each

\footnotetext{
${ }^{2}$ Until 1855, scarlet fever was not distinguished from other diseases such as diphtheria and mumps. However, diphtheria and mumps caused only 2 per cent of deaths in the combined group (see Registrar General 1857, pp. 144$5)$.

Mortality decline by cause/Text/ 6
} 
cause of death. The sum of the direct and indirect effects for any cause of death gives the change in the expectation of life as birth attributable to changes in the ASDRs for that cause. Provided the cause of death classification used is exhaustive (that is, every death is classified somewhere), adding up the direct and indirect effects of all causes of death produces the overall change in the expectation of life at birth.

Extending the period of analysis to the first decade of the twentieth century is worthwhile because the improvement in overall mortality between the 1890s and 1901-1910 was almost as great as that between the 1850s and the 1890s. However, the chronological extension is not straightforward because the Registrar General changed the classification of causes of death slightly between the 1850s and the 1860s, and more extensively between the 1890s and 19011910 (for a full discussion of changes in nosology see Woods, 2000, pp. 312-6; and, on cause-ofdeath statistics in general, see Reid et al., 2015). Moreover, as we have already indicated, these problems are compounded by the failure to distinguish between typhus and typhoid before the 1870 s.

It may therefore be helpful to start with the latter issue. As we have already explained, typhus is a louse-borne disease whereas typhoid — or enteric fever - is waterborne. ${ }^{3}$ However, both diseases were listed under the same heading — typhus—until 1869 (McKeown, 1976, pp. 59-61). During the 1870 s, the death rate from typhus was 0.06 per thousand and the death rate from typhoid was 0.32 per thousand. This reinforces the Registrar General's claim that typhoid, or enteric fever, was responsible for 'the main bulk of the deaths due to fever' during this decade

\footnotetext{
${ }^{3}$ For a full discussion, see MacPherson, 1999, pp. 179, 564-5. In the latest iteration of the International Classification of Diseases (ICD-11) (https://www.who.int/classifications/icd/en/ [accessed 19 January 2019]), typhus is classed a form of rickettsiosis (1C30), whereas typhoid is classed as a bacterial intestinal infection (1A07).

Mortality decline by cause/Text/ 7
} 
(Registrar-General, 1885, p. xiii). However, in the 1850s, the combined death rate from typhus and typhoid was 0.91 per thousand and in the 1860 s it was 0.88 per thousand. It therefore fell very dramatically between the 1860 s and 1870 s, but there is no obvious way of establishing what proportion of the overall decline (from 0.88 to 0.38 per thousand) should be attributed to each disease. $^{4}$

This leads us to consider a wider set of water- and food-borne causes of death, including diarrhoea, dysentery, cholera and typhoid. Table 1 shows the categories used by the Registrar General to report deaths at the level of the registration district in each decade. In the 1850s there were three categories: 'typhus' (which included typhoid), 'cholera, diarrhoea, etc.' and 'diseases of the stomach'. In the 1860s 'cholera' was separated from a category called 'diarrhoea and dysentery'. As we have already seen, the Registrar General did not distinguish between typhus and typhoid (or enteric fever) until the 1870s, when two new categories of 'enteric fever' and 'simple continued fever' were added and the category 'diseases of the stomach' was renamed 'diseases of the digestive system'. The categories used in the 1870s, 1880s and 1890s were the same. In 1901-1910 the category 'simple continued fever' was renamed 'pyrexia' and the category of 'diseases of the digestive system' was discontinued.

[Table 1 about here]

\footnotetext{
${ }^{4}$ Mortality rates have been obtained from the Registrar-General's Decennial Supplements for 1851-1860, 1861-1870 and 1871-1880. Epidemic typhus broke out in England and Wales in the late 1840s among refugees from the famine in Ireland, and it is possible that death rates from the disease continued to be unusually high in the $1850 \mathrm{~s}$ and $1860 \mathrm{~s}$ (in the 1860s the highest death rates in the combined category of typhus and typhoid were reported from Liverpool, where continued epidemics were reported (Hamilton, 1867)). It is also possible that improvements in personal hygiene in the mid-nineteenth century led to a reduction in deaths from typhus (see also Mooney, 2015). For both these reasons, the mix of deaths within the combined category might have changed over time.
}

Mortality decline by cause/Text/ 8 
One obvious question is whether any of the causes of death previously classified as 'diseases of the digestive system' found their way into the category 'diarrhoea and dysentery' in 1901-1910. The Registrar General (1919) states that the category 'diarrhoea and dysentery' used in 1901-1910 includes infective enteritis, epidemic diarrhoea, diarrhoea (not otherwise defined), dysentery and diarrhoea due to food. Other causes of death formerly classed as 'diseases of the digestive system', such as gastritis, gastric catarrh, other non-malignant diseases of the stomach, ulceration of the intestines, and non-epidemic enteritis were not classified as 'diarrhoea and dysentery' in 1901-1910, but were moved into the 'other causes' category. It seems, therefore, that the category described as 'diarrhoea and dysentery' in 1901-1910 is broadly the same as the category given the same name in earlier decades. The only definite change is that deaths from diarrhoea due to food poisoning were moved in 1901 from the category of deaths due to 'violence' to the 'diarrhoea and dysentery' category. However, such deaths comprise only 1,055 out of 103,455 deaths attributed to 'diarrhoea and dysentery' among males, and 851 out of 90,407 deaths attributed to the same causes among females, in 1901-1910 (Registrar General, 1919, p. clxi). The foregoing discussion suggests that a group which combines the Registrar General's 'typhus', 'enteric fever' (from the 1860s onwards) and 'simple continued fever/pyrexia' is consistent across the six decades, and a group which includes 'cholera' and 'diarrhoea and dysentery' (as defined by the Registrar General in each decade) is also broadly congruent.

Table 2 shows the categories used by the Registrar General to describe various forms of tuberculosis. It seems from the descriptions given to the manifestations of this disease that a simple distinction between tuberculosis of the lungs (that is, pulmonary tuberculosis, or phthisis) and other forms of tuberculosis and tuberculous diseases will provide two groups which are 
consistent over time. It has been suggested (Tatham, 1907, p. xcvi; Hardy, 1994; Szreter, 1988, pp. 15-16) that pulmonary tuberculosis deaths were sometimes misclassified as being due to bronchitis or other respiratory diseases. However Guha (1994, pp. 99-100) has provided evidence that pulmonary tuberculosis was distinguished by nineteenth century physicians from bronchitis and other respiratory diseases, mainly on account of its age profile and lack of seasonality (Woods and Shelton, 2000, p. 77).

[Table 2 about here]

Turning to respiratory diseases, from the 1850 s to the 1890 s the Registrar General used a category called 'diseases of the lungs' or 'diseases of the respiratory system'. In 1901-1910 this category was abolished. We have regarded the new 1901-1910 categories 'pneumonia', 'bronchitis' and 'influenza' as equivalent to the previously described 'diseases of the respiratory system'. To analyse this equivalence, we have compared the numbers of deaths reported in England and Wales as a whole in 1901-1910 using two different classification schemes. The first is that given in the registration district data. The second is that given in Registrar General (1919, Table 7, p. clxxxvi), which furnishes a more detailed classification, but also aggregates it in a way different from that reported in the registration district data, giving the number of deaths in a category described as 'diseases of respiratory system (including pneumonia)'. This category included 482,177 male deaths and 425,167 female deaths in the decade 1901-1910. In the registration district data, numbers of deaths are given for the categories 'influenza', 'bronchitis' and 'pneumonia'. The total number of male deaths in these three categories in the decade 19011910 was 472,516, which is 9,661 fewer than the deaths given in Table 7 in the category 'diseases of respiratory system (including pneumonia)', and the total number of female deaths was 427,726, an excess of 2,555. The reasons for these differences are not clear, but the 
comparison suggests that equating the sum of 'influenza', 'bronchitis' and 'pneumonia' deaths in 1901-1910 to 'diseases of the respiratory system' in earlier decades only introduces an error of about 2.0 per cent, and thus it is valid to base our comparison on this. ${ }^{5}$

Fortunately, some of the other categories used by the Registrar General are relatively unproblematic, as they featured in all the different schemes. These were 'smallpox', 'measles', 'scarlet fever', 'diphtheria', 'whooping cough' and 'cancer' ${ }^{6}$ For these categories we have simply taken the deaths allocated to each category by the Registrar General in each decade without attempting to correct them.

The final two causes we consider are 'childbirth' and 'violence'. During the late nineteenth century, deaths due to 'childbirth' included those arising from complications of the pregnancy and birth, as well as puerperal fever. The category of 'violence' included a wide range of accidental deaths and deaths due to poisoning, as well as deaths arising from homicide. The changes of 1901 had the effect of reducing the number of deaths classified as due to 'childbirth' and 'violence' by reclassifying some deaths away from these categories to 'septic diseases' or 'other causes'.

${ }^{5}$ We cannot be sure that the category described as 'diseases of the respiratory system (including pneumonia)' in 1901-1910 is the same as the category called 'diseases of the respiratory system' in earlier decades. Lacking confirmation of this, we have assumed it to be the case.

${ }^{6}$ A slight exception might be made for diphtheria, in that some deaths due to 'membranous laryngitis' were, in 1901, reclassified as being due to bronchitis.

${ }^{7}$ In particular, accidental deaths where death occurred some time after the accident as an indirect result of the injuries sustained (for example due to infection of wounds) were recategorised as being due to 'septic diseases' or 'other causes'. To be included in the category of deaths due to 'violence' in 1901-1910, an accident had to result in 'very severe injuries'. Deaths due to accidents with less severe injuries, industrial poisoning, or an 'opium habit' were put in 'other causes', as were deaths to infants arising from injury at birth, or haemorrhage from the navel. Finally, 'phlegmasia dolens' (also known as 'white leg', and caused by deep vein thrombosis) was in 1901 placed by the Registrar General in the 'other causes' category, even though it was a common symptom of the third trimester of pregnancy.

Mortality decline by cause/Text/ 11 
Table 3 shows the outcome of applying the method of Beltrán-Sánchez et al. (2008) to the resulting set of cause of death groups. The expectation of life at birth rose hardly at all between the 1850 s and the 1860 s. There was, apparently, progress in reducing mortality from pulmonary tuberculosis, but this was cancelled out by an increase in mortality from diseases of the lungs. Significant progress was made between the 1860 s and the 1880 s. The most important contributors to this progress were reductions in mortality from scarlet fever, typhus, typhoid, diarrhoea and dysentery and pulmonary tuberculosis. Progress slowed between the 1880s and the 1890s, largely due to a failure to maintain the decline in mortality from diarrhoeal diseases. However, the period from the 1890 s to $1901-1910$ saw the expectation of life at birth rise by close to half a year per year, as the progress in reducing mortality from diseases of the lungs (which had begun during the previous decade) accelerated, and that due to pulmonary tuberculosis was maintained. Progress in reducing mortality from water- and food-borne diseases resumed between the 1890s and 1901-1910, but at a slower rate than between the 1860s and the 1880s. The decline in mortality from 'other causes' contributed an additional 1.5 years of life between the 1890s and 1901-1910, but this is likely to be an underestimate, as the net effect of the change in the classification scheme was to increase the number of deaths in the 'other causes' group at the expense of some of the other groups used in Table 3, notably 'childbirth' and 'violence'. ${ }^{8}$

[Table 3 about here]

\footnotetext{
${ }^{8}$ The small positive contributions to the increase in the expectation of life produced by 'childbirth' and 'violence' may, therefore, largely be artefacts of these changes to the classification system.
}

Mortality decline by cause/Text/ 12 


\section{Mortality in urban and rural areas}

We now examine how the decline the decline in mortality from individual causes varied between town and countryside. Previous work has highlighted the extent to which mortality was higher in urban than in rural areas, especially in the middle years of the nineteenth century, when rapid migration to the towns and cities threatened to overwhelm the urban infrastructure (Szreter and Mooney, 1998). Whether mortality in large towns actually increased as a result of overcrowding and a deterioration in the urban environment is debatable, but the movement of people from the relatively healthy countryside to the unhealthy towns slowed down — and may have stalled for several decades — the national mortality decline (Woods, 1985).

We have constructed a data base of death rates during the six decades from the 1850 s to 1901-1910 from several major causes of death for 588 registration areas of England and Wales. The data come from Woods (1997) for the 1850s through to the 1890s and from the Registrar General (1919) for 1901-1910. The 588 registration areas are based on the 635 or so registration districts used by the Registrar General to administer the recording of deaths, but we have amalgamated adjacent registration districts in cases where districts were created, abolished, split, or had their boundaries changed substantially, so that we achieve a broadly consistent geography. ${ }^{9}$

\footnotetext{
${ }^{9}$ The registration districts we amalgamated into larger but consistent contiguous areas were as follows: Paddington/Kensington/Fulham, Westminster (St Margaret)/St Martin in the Fields/St James Westminster/Strand, Holborn/Clerkenwell/St Luke, East London/West London/London City, Stepney/Mile End Old Town, St Saviour Southwark/St George Southwark/Newington, St Olave Southwark/Bermondsey/Rotherhithe, Greenwich/Woolwich, Farnham/ Hartley Wintney/ Farnborough, Westhampnett/Chichester, Southampton/South Stoneham, Hendon/Willesden, Ampthill/Woburn/Leighton Buzzard, Lexden/Tendring/Braintree/Witham, Thingoe/Bury St Edmunds, Hartismere/Hoxne, Great Yarmouth (Yarmouth)/Mutford, Tunstead (Smallburgh)/Erpingham, Depwade/Guiltcross/Wayland/Thetford, Alderbury/Salisbury, Tiverton/Dulverton, Bristol/Clifton (Barton Regis)/Bedminster (Long Ashton), Leominster/Presteigne/Kington/Knighton, Nottingham/Radford, Chester (Great Boughton)/Hawarden, Wirral/Birkenhead, Liverpool/Toxteth Park, Manchester/Prestwich, Lancaster/Lunesdale, Ulverston/Barrow-in-Furness, Great Ouseburn/Knaresborough/Otley (Wharfedale)/Wetherby/Tadcaster, Bradford
}

Mortality decline by cause/Text/ 13 
To make a comparison between urban and rural areas we first have to define what we mean by an 'urban' area. More specifically, we need to classify our registration areas according to the degree of 'urban-ness' they possess. Previous attempts to do this for nineteenth century England and Wales have used three criteria: population density, settlement size, and the contiguity of the built-up area (Law, 1967; Robson, 1973; Bennett, 2012, see Smith et al., 2018, pp. 574-5 for a discussion). Historically, a population density of one person per acre (2.5 persons per hectare) has been regarded as a minimum for an area to be classed as urban (Law, 1967; Robson, 1973). However, this has a tendency to classify too many places as urban, in particular rural areas with fairly dense but non-contiguous settlement, such as mining districts and zones close to large towns and cities with a suburban character. We have therefore divided the 588 registration areas into four groups based on their population density in 1881 (the midpoint of our period): under 1 person per acre, 1-3 persons per acre, 3-10 persons per acre, and more than 10 persons per acre. Following Woods (2000), the areas with more than 10 persons per acre have been separated into London districts and districts outside London. For the districts within each category, Table 4 presents aggregate cause-specific death rates for diarrhoeal diseases, typhus and typhoid, scarlet fever, phthisis (pulmonary tuberculosis) and diseases of the lungs for each decade from the 1850s to 1901-1910. The right-hand columns of Table 4 express the aggregate death rates in each type of area in each decade as a percentage of the corresponding death rates in 1861-1870.

[Table 4 about here]

[Yorkshire]/North Bierley, Hunslet/Holbeck/Bramley, Guisborough/Middlesbrough/Stockton/Hartlepool/Sedgefeld, Lanchester/Durham, Abergavenny/Bedwelty, Cardiff/Pontypridd, Neath/Pontardawe, Swansea/Gower, and Anglesey/Holyhead.

Mortality decline by cause/Text/ 14 
The overall results reinforce those shown in Table 3. There was little change in the overall death from either diarrhoeal diseases or the somewhat problematic group of 'typhus and typhoid' between the 1850s and 1860s, but death rates from these diseases declined between the 1860 s and 1880s and again between the 1880s and early-1900s. The death rate from phthisis, or pulmonary tuberculosis, fell steadily from the 1850s onwards, although there are some indications of an acceleration in the rate of decline between the 1860s and 1890s. The death rate from scarlet fever rose between the 1850s and 1860s before declining rapidly. The death rate from diseases of the lungs rose between the 1850s and 1870s and stagnated between the 1870s and 1880 s, before declining from the 1880 s onwards.

Although these results conceal some variations in the rates of decline between different types of area, these variations are smaller than might be expected. In absolute terms, the decline in mortality was always greatest in urban areas and, outside London, the size of the decline increased in accordance with the degree of 'urban-ness'. However, the relative rates of decline for some causes of death were quite similar. Mortality from scarlet fever declined at similar rates in all types of area outside London. In the metropolitan districts the decline was earlier and more rapid. ${ }^{10}$ From 1861, phthisis mortality declined roughly in parallel in all areas, including London, although the decline in the tuberculosis death rate was slower in the most denselypopulated areas from the 1880 s onwards. Mortality from diseases of the lungs increased more sharply in rural areas than urban areas between the 1860s and 1870s, but declined at similar rates in all types of area from the 1880s.

\footnotetext{
${ }^{10}$ The fact that scarlet fever mortality declined earlier in London than elsewhere in the country is interesting in the light of the generally accepted view that a decrease in the virulence of the causative agent was mainly responsible. Did the less virulent form appear earlier in London than elsewhere?
}

Mortality decline by cause/Text/ 15 
The combined rate of mortality from typhus and typhoid declined more rapidly between 1861-1870 and 1871-1880 in areas with more than 3 persons per acre than in rural areas and areas with 1-3 persons per acre, so that overall there was convergence between urban and rural areas.

The rates at which mortality from diarrhoeal diseases and dysentery declined are particularly interesting. The level of mortality from these causes in the 1850 s varied dramatically with population density (areas with more than 10 persons per acre had death rates 2.5 times (London) and more than 3 times (outside London) those in areas with under 1 person per acre). Mortality from these causes in urban areas declined earlier and more rapidly than mortality in rural areas between the 1860 s and 1880 s, but this pattern was reversed when the decline resumed during the 1890s and 1900s. Rural areas lagged behind, and urban areas with between 1 and 3 persons per acre not only lagged behind but experienced smaller relative decline over the 60 years than other areas.

Taken as a whole, the evidence from Table 4 suggests that, for some causes of death, including others which might also have been associated with poor urban environments, mortality declines in rural areas largely proceeded at a similar pace, and with a similar chronology, to those in urban areas. The rates of mortality decline from scarlet fever were very similar across areas with different population densities, especially after the 1860s, and those from pulmonary tuberculosis, or phthisis, were almost identical. Indeed, not only were the relative declines similar, but the levels of phthisis mortality also varied little with population density.

For diarrhoeal mortality and mortality from typhus and typhoid there were differences between urban and rural areas. The combined rates of mortality in both 'urban' and 'rural' areas were almost constant between the 1850s and 1860s, and then declined between the 1860s and 
1880s. From the 1860 s onwards, the most rapid declines in death rates from these causes took place in the most densely populated areas and, above all, in London. For diarrhoeal diseases there was a period of stagnation between the 1880 s and 1890 s before mortality decline resumed between the 1890s and 1901-1910. In this second phase of the decline, rural areas made more rapid progress than urban areas. For neither cause was there a clear and monotonic association between the relative decline in death rates and population density. Notably, in the first phase of the decline, the relative progress of 'lightly urbanised' areas (with population densities of 1-3 persons per acre) lagged behind even rural areas.

One possible reason for the rather weak association between the relative declines in cause-specific mortality and the degree of urbanisation as measured by population density is that the latter does not actually measure the proportion of the population living in areas that are recognisably urban in character. Law (1967, pp. 129-32); and Robson (1973, pp. 47-52) proposed that urban settlements should have a spatially continuous built-up area with a population of 2,500 or more. Woods (2000, pp. 360-2) suggests that, for examining the association between urban life and mortality in the second half of the nineteenth century, a minimum size threshold of 10,000 inhabitants is more realistic. Following Woods, we have established, for each of the 588 geographical areas, the percentage of the population living in urban areas with populations of 10,000 or more inhabitants in 1881. Urban places were identified using the Urban Population Database (Bennett, 2012). We then divided the 588 areas into four groups according to this percentage ( 0 , more than zero but under 60 per cent, $60-90$ per 
cent and 90 per cent or more) and computed cause-specific death rates as before (Table 5). ${ }^{11}$

Within the category of areas with 90 per cent or more of their populations being urban, we distinguished London from other areas.

\section{[Table 5 about here]}

The results are very similar to those obtained when defining urban and rural areas on the basis of population density. Mortality was much higher in urban areas than in rural areas, and was highest in those areas with populations that were 90 per cent urban or more. These were the areas which experienced the greatest declines in mortality in absolute terms. However, relative declines in cause-specific mortality in areas with different proportions living in towns with 10,000 or more inhabitants were sometimes similar and, where they did vary, did not exhibit an obvious gradient from the least to the most urbanised. Thus, for example, it is the areas including some urban people, but with less than 90 per cent of their populations in urban areas, that exhibited the slowest declines in mortality from diarrhoeal diseases, and from typhus and typhoid. Mortality from typhus and typhoid, and from scarlet fever, converged on very low levels by 1901-1910 in all types of area. However the decline in typhus and typhoid occurred earliest in heavily urbanised areas, and especially in London. Mortality from pulmonary tuberculosis declined in parallel across the four types of area.

\footnotetext{
${ }^{11}$ This classification has the advantage that it also distinguishes quite well between people living in Woods's (2000, pp. 368-72) 'large towns' (populations of over 100,000) and 'small towns' (populations of 10,000-100,000). None of the urban places contributing to the urban population of those areas with some, but less than 60 per cent, of their populations in urban areas had more than 100,000 inhabitants. Most of the urban inhabitants of areas with 60-90 per cent or over 90 per cent of their populations living in urban areas lived in towns with populations of more than 100,000 . Woods (2000, pp. 368-72) showed that overall mortality was greater in 'large towns' than in smaller towns.
}

Mortality decline by cause/Text/ 18 


\section{Discussion}

The causes of death which contributed most substantially to the mortality decline in England and Wales were waterborne, food-borne and airborne infections. Between the 1850s and 1901-1910 the expectation of life at birth in England and Wales for the sexes combined rose from 40.68 years to 49.73 years, an increase of 9.05 years. ${ }^{12}$ Of this increase, 2.25 years ( 25 per cent) was due to a decline in mortality from pulmonary tuberculosis, 1.56 years ( 17 per cent) was due to a decline in death rates from waterborne diseases plus typhus, 1.19 years (13 per cent) was due to scarlet fever, and 0.58 years (6 per cent) was due to diseases of the lungs. 'Other causes' contributed 3.5 years ( 39 per cent). The remaining named causes in Table 3 had small effects, and their total net impact on mortality was zero.

It might be asked how our new estimates of the contributions of different causes compare with those made by previous analysts, notably Woods (2000, pp. 350-1). Woods analysed the percentage contributions of different causes of death to the change in mortality between 18611870 and 1891-1900 using standardised death rates. Table 6 compares his estimates with our new estimates for the same period, together with our estimates for the period 1851-1860 to 19011910. Our estimates and Woods's estimates are fairly close, but our estimates for the period from the 1860 s to the 1890 s give greater weight to causes of death that affected children (such as measles, scarlet fever and whooping cough) and less weight to causes of death that affected mainly adults (such as cancer and violence). ${ }^{13}$ Comparing our figures for the period 1851-1860

\footnotetext{
12 These expectations of life are the result of using the data in Woods (1997) and Registrar General (1919) to calculate life tables for the sexes combined.

13 This is to be expected, as our estimates of the contribution of each cause of death are based on its effect on the expectation of life. Deaths at younger ages curtail life by more years than do deaths at older ages.
}

Mortality decline by cause/Text/ 19 
to 1901-1910 shows that contributions of scarlet fever, waterborne diseases plus typhus, and pulmonary tuberculosis have been reduced and replaced mainly by diseases of the lungs. The relative contribution of scarlet fever over the period 1851-1860 to 1901-1910 is only about half its relative contribution over the shorter period 1861-1870 to 1891-1900, reflecting the fact that almost the whole of the decline in death rates from this cause happened between the 1860s and the 1890s. It made almost no contribution to the large increase in the expectation of life between 1891-1900 and 1901-1910.

\section{[Table 6 about here]}

The biggest impact on mortality from waterborne diseases was felt between the $1860 \mathrm{~s}$ and the 1880s (see Tables 4 and 5). However, the exact contribution of waterborne diseases to the dramatic decline between the 1860s and the 1870s is not known, as we cannot ascertain what percentage of the overall decline in mortality from typhus and typhoid was associated with the former disease. The apparent second peak in the contribution of waterborne diseases to the decline of mortality between the 1890s and 1901-1910 is partly due to the elevation of infant mortality from diarrhoeal diseases due to a series of warm summers in the 1890s (see Woods et al., 1988), which was also responsible for the apparent reversal of progress from this cause of death between the 1880 s and the 1890 s. Airborne infections were in consistent decline throughout the period, although their impact on total mortality seems to rise over time.

Recent explanations of the decline in mortality from these causes have often focused on the role of public investment in sanitation and other environmental improvements (see, for the United States, Cutler and Miller, 2005; and Ferrie and Troesken, 2008; for Paris, Kesztenbaum and Rosenthal, 2017; and for Tokyo, Ogasowara et al., 2018). In the case of England and Wales, the literature which attempts to link public investment in infrastructure to improvements in Mortality decline by cause/Text/ 20 
mortality from infectious diseases has paid particular attention to larger towns and cities (for example Bell and Millward, 1998; Millward and Bell, 1998; Chapman, 2018) and there is a tendency to consider as relevant investments those which tackled urban problems. Attention has focused on analysing the association between loans taken out by local authorities for investing in infrastructure (and the investments to which they gave rise) and mortality decline, taking advantage of time- and place-specific data to provide the variation needed to assess the strength of the association. ${ }^{14}$

Chapman (2018) measures public investment using the value of loans outstanding, and his analysis reveals a strong impact of outstanding debt on both overall mortality change, and on changes in mortality from waterborne and airborne diseases. He suggests that in these urban areas (which included both large cities and small towns) about 60 per cent of the decline in mortality between 1861 and 1900 could be accounted for by infrastructure investment as measured by outstanding debt. However, Chapman's measure of public investment does not accurately identify when that investment took place, or (until 1884) what the money was spent on. So, for example, a town with a large outstanding loan in, say, 1871, may have taken that loan out 20 or more years earlier, and made the consequent investment many years before, or it may have just contracted the loan and be yet to spend the money. The value of debt outstanding also reflects the rate at which debt is repaid, so may have depended on the repayment terms. ${ }^{15}$

\footnotetext{
${ }^{14}$ Sir John Simon, London's first Medical Officer of Health, was in no doubt that the most accurate barometer of investment in public health was the value of the loans taken out by local authorities for the stated purposes of making such investments (Wohl 1983, pp. 112-3). John Simon was appointed Medical Officer of Health to the City of London in 1848, but he moved to the (second) General Board of Health in 1854 and to the Medical Department of the Privy Council in 1858. However, at the time when he commented on the value of loans as barometers of sanitary activity, he was Medical Officer to the Local Government Board.

${ }^{15}$ Chapman (2018) uses an instrumental variable in his approach to avoid bias in the estimates caused by, for example, a one-off rise in mortality that triggered an investment. But his chosen instrument, which is the volume of
}

Mortality decline by cause/Text/ 21 
Harris and Hinde (2019) have recently estimated the total value of the loans for which approval was sought either by local authorities or private undertakings for water- or healthrelated purposes in non-metropolitan urban areas in each year from 1817 to 1914. This approach to the loans almost certainly takes us closer to the date the expenditure was made than the retrospective approach using outstanding debts, although it is still not perfect, as local authorities may have delayed spending the money for some years after loans were approved, and some expenditure may not have happened at all. ${ }^{16}$ Until the mid-1860s, the average value of the loans for which approval was sought was less than $£ 1,000,000$ per year (at 1900 prices). There was an increase around 1865 to around $£ 2,000,000-£ 3,000,000$ per year, and a short-lived surge in 1879 and 1880, but the greatest activity (measured in terms of the value of loans taken out per year), occurred between 1890 and around 1905. This suggests that the initial increase in sanitary expenditure was associated with the onset of the decline in mortality from waterborne diseases during the 1860s and 1870s, and that the acceleration in sanitary investment during the $1890 \mathrm{~s}$

debt outstanding in the preceding decade, suffers from the same problems in its relation to the incurring of expenditure as the original variable. It is also not clear that lagged debt is associated with mortality only through its effect on current debt (an assumption of the instrumental variable method). For example, suppose a town took out a loan of $£ 50,000$ in 1870 , constructed a sewage works in 1872, and then repaid the loan in full in 1880. Its lagged debt in the 1880s would be $£ 50,000$. Its current debt in the 1880 s would be zero. It seems unrealistic to assume that the construction of the sewage works in 1872 had no effect on mortality. The real issue is whether past expenditure explains current achievements. Such expenditure could be reflected in both past and present debts.

\footnotetext{
${ }^{16}$ In many cases approval was sought for loans only when expenditure was imminent. The process by which application for approval was made required local authorities to give details of the purposes for which money was required, so the planning of investment was usually at a fairly advanced stage when permission to borrow the money was granted. As Harris and Hinde (2019) explain, the sanctioning authorities (the General Board of Health, the Local Government Act Office [part of the Home Office] and subsequently the Local Government Board) monitored what happened with the approved loans and made it clear that the sanctioning of future borrowing would be conditional on the satisfactory handling of previous authorisation (by which they meant the timely borrowing of funds and expenditure for the purposes for which approval had been granted). The records of loans taken out between 1850 and 1871, held in The National Archive HLG 15/1-8, include occasional references to loans that were not, in the event, taken up. If these references are, effectively, the visible imprint of the monitoring system, then such occurrences only characterised a small fraction of all the loans.
}

Mortality decline by cause/Text/ 22 
and early-1900s was associated with the renewed decline of mortality from these diseases from the 1900s onwards. However, it is more difficult to associate this pattern with the geography of the decline in mortality from these diseases. If sanitary investment was responsible for the decline of these mortality rates in urban areas, why were mortality rates also declining in rural areas?

One approach to this question would be to compare rates of investment in the two types of area. Unfortunately, we have not yet tried to analyse the value of the loans sought by rural sanitary authorities in any detail. However, the Local Government Board did publish figures showing the total value of the loans sought by both urban and rural sanitary authorities from 1873 onwards (see Harris and Hinde, 2019, p. 5), and we can use this information to compare the aggregate value of loans in the two types of area. These figures are depicted graphically in Figure 1. They show that rural sanitary authorities borrowed far less, per head of population, than urban authorities and that there was relatively little change in the rate of rural borrowing before the 1890s. Insofar as these figures suggest that loan-financed investments made relatively little contribution to the decline of mortality in rural areas before this point, they also suggest that the question of why mortality declined in these areas deserves far more attention than it has hitherto received.

[Figure 1 about here]

At a general level, therefore, there is some evidence, but by no means conclusive, that public investment was associated in some way with mortality decline, especially in urban areas. Public investment in water and other health-related activities peaked in 1899, and this peak was associated with an acceleration of the decline in mortality, but a geographical analysis of the association between investment and mortality change after 1900 has yet to be attempted. Even 
for the period up to the 1890 s, most existing research has not been able to associate the timing and location of specific improvements to the infrastructure with consequent mortality declines in the same locations. ${ }^{17}$ It is, furthermore, unlikely that the Local Taxation Returns will allow us to do this. The loans data, however, offer a better chance, assuming that the date of the actual investment is roughly approximated by the date of the loan being sanctioned or approved, which is probably true in most cases (see Harris and Hinde, 2019).

Although we have discerned some differences in the rates at which mortality from diarrhoeal diseases declined in urban as opposed to rural areas, this was less true of other types of disease. Our current results suggest that, so far as these other diseases were concerned, although the largest declines in mortality in absolute terms took place in urban areas, there was little difference in relative rates of decline and it may be closer to the truth to say that causespecific mortality declined in parallel in town and countryside. This is almost exactly true of the single biggest contributor to the decline, pulmonary tuberculosis, and largely true of diseases of the lungs. These results raise many questions. Why did phthisis mortality decline in parallel in towns and cities? Given the low level of investment in infrastructure in rural areas, were there other determinants of mortality decline in the countryside? If the latter, did these determinants operate in towns and cities as well? And what factors delayed mortality decline in smaller urban areas?

\footnotetext{
${ }^{17}$ Some researchers have attempted to date specific investments and to follow them through to examine their impact on mortality. One example relates to loans taken out to allow local authorities to buy private waterworks. Beach $e t$ al. (2016) examined the municipalisation of a sample of urban waterworks and showed that deaths from typhoid fell, on average, by about 19 per cent following their transfer to public ownership. Even here, the effect was much greater for waterworks purchased after 1880 than for waterworks purchased before that date, so this is unlikely to explain the rapid fall in death rates from typhus and typhoid between the 1860s and the 1880s.
} 
To answer these questions, it would be worth increasing our research effort into understanding mortality changes in smaller towns and rural areas, which have been rather neglected compared with larger towns and cities (exceptions are Hastings et al., 2015; Sneddon, 2006; and Hinde and Fairhurst, 2015). One possible explanation for the slow progress on waterborne and food-borne diseases in smaller towns is that they lacked three elements central to the effective implementation of sanitary reform: first, the conviction that they had a sanitary or environmental problem to be solved (the 'urban penalty' being seen by those running smaller towns as a problem of major cities); second, the skills to advocate and implement sanitary reform among their administrative and local government leaders; and, third, the fiscal capacity to generate the revenue from rates needed to obtain loans. One of the few pieces of research on a small town is Vaile's (2015) case study of the town of Sandwich in Kent, a town even smaller than those we have identified as lagging behind. He shows that the town council was largely uninterested in public health matters during the 1870 s, even though it eventually agreed to appoint a Medical Officer of Health (MOH) in 1878, having been required to do so by the 1875 Public Health Act. The MOH presented annual reports to the council starting in 1879, which raised concerns about the water supply (Vaile 2015, p. 104). The council largely ignored these until, in 1882, an event occurred which could not be ignored: the death of the mayor from typhoid. ${ }^{18}$ This did galvanise the council into taking action, but it was still 12 years before a new

\footnotetext{
${ }^{18}$ The death from infectious diseases of prominent individuals was one way in which the threat posed by these diseases was brought home to the general public. For example, Wohl (1983, pp 1-2) mentions the death from typhoid of Prince Albert, husband of Queen Victoria, in 1861, and the illness of their eldest son in 1871, in this regard.
}

Mortality decline by cause/Text/ 25 
waterworks was opened in $1894 .{ }^{19}$ Richardson $(2007,2008 \mathrm{a}, 2008 \mathrm{~b})$ shows that the members of the Rural Sanitary Authority in the small town of Uppingham in Rutland were overwhelmed by the scale of the work involved in improving the town's water supply following a typhoid epidemic in 1875. Other work in rural areas (Hastings et al., 2015) has suggested that efficient administration was an important contributor for the effective tackling of infant mortality. ${ }^{20}$

Finally, work on examining the impact of public investment on mortality in England and Wales has hitherto tended to concentrate on sanitation and water- and food-borne infections. Yet, while these were important, other causes of death which contributed to the decline in mortality have been relatively neglected. Chief among these is pulmonary tuberculosis. The relative absence of studies into the role played by the public health movement in the decline of mortality from phthisis may be due to the belief that mortality from phthisis was mainly associated with nutrition (McKeown, 1976) and particularly with a lack of adequate nutrition for females as a result of their poor bargaining position within poor Victorian households (see, for example, Anderson, 1990; Johansson, 1977, 1996; and McNay et al., 2005). However, although Floud et al. (2011, pp. 151-64; see also Harris, Floud and Hong 2015) have argued that there was a substantial increase in the number of calories available for human consumption in England and Wales between circa 1850 and 1909/13, the evidence supporting a bargaining-nutrition account of geographical patterns in the sex ratio of phthisis mortality in the 1860s is quite equivocal

\footnotetext{
${ }^{19}$ Our loan data show that the council secured approval from the Local Government Board for a loan of $£ 675$ for 'water supply' in 1891 and for a series of water-related loans, totalling £8,800, in 1893 (see Local Government Board, 1892, p. 514; 1894, p. 482).

${ }^{20}$ Hanley (2016) and Rosenthal (2014) also deal with administrative matters with a bearing on public health (the definition of the 'public' and the 'private', and legal and economic aspects of water-borne nuisances respectively).
}

Mortality decline by cause/Text/ 26 
(Hinde, 2015; and Reid and Garrett, 2018). ${ }^{21}$ Scepticism about the nutritional account has also been expressed by Szreter (1988), Woods (2000) and others. This suggests that we should look at alternatives. Contemporaries such as Newsholme (1908) considered that improved isolation of tuberculosis cases and the consequent reduction in the rate of transmission of the disease was critical to the decline in death rates (see also Wilson, 2005). It is also possible that improvements in sanitation and hygiene had an indirect effect on mortality from tuberculosis (Preston and van de Walle, 1978), and Harris (2004) discussed the possible link between tuberculosis and housing, noting that the introduction of better by-laws might have helped to improve the quality of the housing stock. ${ }^{22}$ Investigations into the impact of public health initiatives on the decline of mortality from phthisis might thus find that they played a more important role than has hitherto been thought. $^{23}$

\section{Conclusion}

This paper has presented a new analysis of the influence of different causes of death on the expectation of life at birth, and the evolution of mortality by cause of death in urban and rural England and Wales. We have described a data set which allows the comparison of mortality from those causes which were most important to the decline of mortality across a consistent set of 588 registration areas for six decades from the 1850s to 1901-1910. In particular, we have extended

\footnotetext{
${ }^{21}$ Harris (2008) also pointed out that the bargaining-nutrition account relies on a concept of 'excess female mortality' which is often ill-defined.

${ }^{22}$ Though, in addition, he noted that rising real wages enabled people to afford better housing, and fertility decline may have helped to reduce domestic overcrowding.

23 Another issue which has received renewed attention recently is the issue of atmospheric pollution (see Beach and Hanlon, 2018; and Bailey et al., 2018).
}

Mortality decline by cause/Text/ 27 
previous analyses of the nineteenth century decline to the first decade of the twentieth century. This is important because the magnitude of the mortality decline between the 1890s and 19011910 was almost as great as that in the preceding four decades put together, but challenging because the Registrar General made (apparently) extensive changes to the cause of death classification scheme in 1901. We discuss these changes, and show that it is possible to devise a set of cause of death categories which are comparable across the six decades from the 1850 s to 1901-1910.

Our main conclusions are as follows.

1. The causes which contributed most to the decline of mortality between 1850 and 1910 were, in descending order, pulmonary tuberculosis, a group comprising water- and foodborne infections plus typhus, scarlet fever, and diseases of the lungs. The relative contributions of these causes depend on the range of time over which the decline is being considered. For example, previous work that focused on the decades 1861-1870 to 18911900 tended to emphasise the impact of the rapid decline in mortality from scarlet fever, as the decline in mortality from this cause was more rapid during this period than before or afterwards. Including the period 1891-1900 to 1901-1910 brings out the importance of bronchitis and pneumonia.

2. Our analysis shows that, throughout the period, mortality rates from all the major disease groupings were highest in urban areas. Urban areas also witnessed the greatest declines in mortality, in absolute terms, from all types of disease. However, the relative rates of decline from pulmonary tuberculosis, diseases of the lungs and (apart from London) scarlet fever were similar across all areas. For waterborne and food-borne diseases (plus typhus) the pace of mortality decline was greater in rural areas than in what might be 
described as 'moderately urban' areas but, between the 1860s and the 1880s, it was fastest of all in the most densely-populated large towns, including London.

3. At a national level, the evidence suggests that there was a broad similarity between the chronology of increases in sanitary investment, as reflected in the value of the loans sought by non-metropolitan urban areas, and the chronology of mortality decline from the kinds of diseases which were most likely to respond to such investments. This similarity extends at the aggregate level to the urban and rural areas. However, it is more difficult to reconcile public investment with the chronology of the decline in mortality from pulmonary tuberculosis.

4. The similarities and differences in the pace and timing of the decline in mortality from waterborne diseases in different types of area suggest that more attention should now be paid to the decline of mortality in smaller towns and rural areas.

Much remains to be done to examine cause-specific mortality decline and the role of investment in public health in promoting the decline of mortality. More case studies of specific places would be helpful, of both large and small towns, and of rural areas. These would allow international comparisons with large towns and cities in the United States and with countries such as Sweden, where towns were smaller. Such case studies would help shed more light on an issue that we have not been able to settle in this paper: how important for the effectiveness of investment in public health was efficient public administration (Szreter, 2005)? Another useful piece of work would be to extend the evaluation of the impact of infrastructure investment on mortality decline into the early twentieth century. The fact that the deaths by age and cause for 1901-1910 have not been rendered machine readable means that this is a substantial undertaking, yet it is important to remember that the improvement in the expectation of life between the $1890 \mathrm{~s}$ 
and 1901-1910 was almost as great as in the previous four decades put together. Finally, the biggest single contributor to the decline of mortality in England and Wales over the 60-year period from 1850 to 1910 was pulmonary tuberculosis. Its decline was steady, ubiquitous and relentless. Yet we still are very unclear why it happened, or the extent to which it was influenced by public investment or public policy. 


\section{References}

Anderson, M. (1990). The social implications of demographic change. In F.M.L. Thompson (ed.), The Cambridge Social History of Britain, 1750-1950: People and their Environment (Vol. 2. Cambridge: Cambridge University Press, pp. 1-70.

Bailey, R., Hatton T. and Inwood, K. (2018). Atmospheric pollution, health and height in latenineteenth century Britain. Journal of Economic History. Published online 23 November 2018. https://doi.org/10.1017/S0022050718000578.

Beach, B. and Hanlon, W.W. (2018) Coal, smoke and mortality in an early industrial economy, Economic Journal 128, pp. 2,652-75. http://doi.org/10.1111/ecoj.12522.

Beach, B., Troesken, W. and Tynan, N. (2016) Who should own and control urban water systems? Historical evidence from England and Wales (National Bureau of Economic Research working paper no. 22553). Cambridge, Mass.: National Bureau of Economic Research.

Bell, F.N. and Millward, R. (1998) Public health expenditures and mortality in England and Wales, 1870-1914, Continuity and Change 13: 211-49.

Beltrán-Sánchez, H., Preston, S.H. and Canudas-Romo, V. (2008) An integrated approach to cause of death analysis: cause-deleted life tables and decomposition of life expectancy, Demographic Research 19: 1,323-50. http://doi.org/10.4054/DemRes.2008.19.35.

Bennett, R.J. (2012) Urban Population Database, 1801-1911. [data collection]. UK Data Service. SN: 7154. http://doi.org/10.5255/UKDA-SN-7154-1.

Chapman, J. (forthcoming) The contribution of infrastructure investment to Britain's urban mortality decline 1861-1900, Economic History Review. http://doi.org/10.1111/ehr.12699. Cutler, D.M. and Miller, G. (2005) The role of public health improvements in health advances: the twentieth-century United States, Demography 42: 1-22.

Mortality decline by cause/Text/ 31 
Ferrie, J. and Troesken, W. (2008) Water and Chicago's mortality transition, 1850-1925. Explorations in Economic History 45: 1-16.

Floud, R., Fogel, R., Harris, B. and Hong, S.C. (2011), The changing body: health, nutrition and human development in the western world since 1700. Cambridge, Cambridge University Press. Gatley, D. (1997) Computerising the 1861 Census Abstracts and Vital Registration Statistics, Local Population Studies 58: 37-47.

Guha, S. (1994) The importance of social intervention in England's mortality decline: the evidence reviewed. Social History of Medicine 7: 89-113. https://doi.org/10.1093/shm/7.1.89. Hamilton, R. (1867) The epidemics of typhus and cholera in Liverpool. The Lancet 90, 2311: 731-3. https://doi.org/10.1016/S0140-6736(02)55149-7.

Hanley, J. (2016) Healthy Boundaries: Property, Law and Public Health in England and Wales, 1815-1872. Woodbridge: Boydell and Brewer.

Hardy, A. (1994). 'Death is the cure of all diseases': Using the General Register Office cause of death statistics for 1837-1920. Social History of Medicine 7: 472-92.

http://doi.org/10.1093/shm/7.3.472.

Harris, B. (2004) Public health, nutrition and the decline of mortality: the McKeown thesis revisited, Social History of Medicine 17: 379-407. https://doi.org/10.1093/shm/17.3.379. Harris, B. (2008) Gender, health and welfare in England and Wales since industrialisation. In A.J. Field, W.A. Sundstrom and G. Clark (eds) Research in Economic History 26. Bingley, Emerald Group, pp. 157-204. https://www.emeraldinsight.com/doi/pdfplus/10.1016/S03633268(08)26003-9.

Mortality decline by cause/Text/ 32 
Harris, B. and Hinde, A. (2019) Sanitary investment and the decline of urban mortality in England and Wales, 1817-1914, The History of the Family. http://doi.org/10.1080/1081602X.2018.1556722.

Harris, B., Floud, R. and Hong, S.C. (2015), How many calories? Food availability in England and Wales in the $18^{\text {th }}$ and $19^{\text {th }}$ centuries. In C. Hanes and S.K. Wolcott (eds) Research in Economic History, 31. Bingley, Emerald Group, pp. 111-91. https://doi.org/10.1108/S0363326820150000031003.

Hastings, S.G., Gregory, I. and Atkinson, P.D. (2015) Explaining geographical variations in English rural infant mortality decline using place-centered reading, Historical Methods 48: 12840. https://doi.org/10.1080/01615440.2014.995390.

Hinde, A. (2015) Sex differentials in phthisis mortality in England and Wales, 1861-1870. The History of the Family 20: 366-90. http://doi.org/10.1080/1081602X.2015.1051077.

Hinde, A. and Fairhurst, V. (2015) Why was infant mortality so high in eastern England in the mid-nineteenth century? Local Population Studies 94: 48-66.

Johansson, S. R. (1977) Sex and death in Victorian England: an examination of age- and sexspecific death rates, 1840-1910. In M. Vicinus (ed.), A Widening Sphere: Changing Roles of Victorian Women. London: Methuen, pp. 163-81.

Johansson, S. R. (1996) Excess female mortality': constructing survival during development in Meiji Japan and Victorian England. In A. Digby and J. Stewart (eds.), Gender, Health and Welfare. London: Routledge, pp. 32-66.

Kesztenbaum, L. and Rosenthal, J-L. (2017) Sewers' diffusion and the decline of mortality: the case of Paris, 1880-1914', Journal of Urban Economics 98: 174-86.

https://doi.org/10.1016/j.jue.2016.03.001.

Mortality decline by cause/Text/ 33 
Local Government Board (1892) Twenty-first Annual Report of the Local Government Board, 1891-2 (British Parliamentary Papers 1892 [C. 6745]). London: Her Majesty's Stationery Office. Local Government Board (1894) Twenty-third Annual Report of the Local Government Board, 1893-4 (British Parliamentary Papers 1894 [C. 7500]). London: Her Majesty's Stationery Office. Law, C.M. (1967) The growth of the urban population of England and Wales, 1801-1911, Transactions of the Institute of British Geographers 41: 125-43. http://doi.org/10.2307/621331.

MacPherson, G. (1999) Black's Medical Dictionary. London: A. \& C. Black.

McKeown, T. (1976) The Modern Rise of Population. London: Arnold.

McKeown, T. and Record, R.G. (1962) Reasons for the decline of mortality in England and Wales during the nineteenth century, Population Studies 16: 94-122.

\section{http://doi.org/10.1080/00324728.1962.10414870.}

McNay, K., Humphries, J. and Klasen, S. (2005) Excess female mortality in nineteenth-century England and Wales: a regional analysis. Social Science History 29: 649-81. https://doi.org/10.1017/S0145553200013341.

Mercer, A. (2014) Infections, Chronic Disease, and the Epidemiological Transition: a New Perspective. Woodbridge: Boydell and Brewer.

Millward, R. and Bell, F.N. (1998) Economic factors in the decline of mortality in latenineteenth century Britain, European Review of Economic History 2: 263-88. https://doi.org/10.1017/S1361491698000124.

Mooney, G. (2015) Intrusive Interventions: Public Health, Domestic Space and Infections Disease Surveillance in England, 1840-1914. Woodbridge: Boydell and Brewer.

Newsholme, A. (1908) The Prevention of Tuberculosis. London: Methuen. 
Ogasowara, K., Shirota, S. and Kobayashi, G. (2018) Public health improvements and mortality in interwar Tokyo: a Bayesian disease mapping approach, Cliometrica 12: 1-31.

Preston, S H. and van de Walle. E. (1978) Urban French mortality in the nineteenth century, Population Studies 32: 275-97.

Registrar General (1857) Eighteenth Annual Report of the Registrar General of Births Deaths and Marriages in England (British Parliamentary Papers 1857,2 XXII [C. 2260]). London, Eyre and Spottiswoode, pp. 144-45.

Registrar General (1885) Supplement to the Forty-Fifth Annual Report of the Registrar-General of Births, Deaths and Marriages in England (British Parliamentary Papers 1884-85 XVII [C. 4564]). London: Eyre and Spottiswoode.

Registrar General (1919) Supplement to the Seventy-Fifth Annual Report of the RegistrarGeneral of Births, Deaths and Marriages in England and Wales: part III. Registration Summary Tables (1901-1910) (British Parliamentary Papers 1914-16 VIII [Cd. 8002]). London: His Majesty’s Stationery Office.

Reid, A. and Garrett, E. (2018) Mortality, work and migration: a consideration of age-specific mortality from tuberculosis in Scotland, 1861-1901, Historical Life Course Studies 6: 111-32. Reid, A., Garrett, E., Dibben, C. and Williamson, L. (2015) 'A confession of ignorance': deaths from old age and deciphering the cause-of-death statistics in Scotland, 1855-1949, The History of the Family 20: 320-44. https://doi.org/10.1080/1081602X.2014.1001768.

Richardson, N. (2007) The Uppingham typhoid outbreaks of 1875-1877: A rural case-study in public health reform, Social History of Medicine 20: 281-96.

https://doi.org/10.1093/shm/hkm041.

Mortality decline by cause/Text/ 35 
Richardson, N. (2008a) Typhoid in Uppingham: Analysis of a Victorian Town and School in Crisis. Pittsburgh: University of Pittsburgh Press.

Richardson, N. (2008b) Typhoid in Uppingham, Rutland, 1875-1877: reassessing the social context, Local Historian 38: 274-88.

Robson, B. (1973) Urban Growth: an Approach. London: Routledge.

Rosenthal, L. (2014) The River Pollution Dilemma in Victorian England: Nuisance Law verses Economic Efficiency. Farnham: Ashgate.

Smith, H; Bennett, R.J. and Radicic, D. (2018) Towns in Victorian England: a new classification, Urban History 45: 568-94. https://doi.org/10.1017/S0963926818000020.

Sneddon, S. (2006) A double penalty? Infant mortality in the Lincolnshire Fens, 1870-1900. In

E. Garrett, C. Galley, N. Shelton and R. Woods (eds), Infant Mortality: a Continuing Social Problem. Aldershot: Ashgate, pp. 79-97.

Szreter, S. (1988) The importance of social intervention in Britain's mortality decline c.18501914: a re-interpretation of the role of public health', Social History of Medicine 1: 1-37. https://doi.org/10.1093/shm/1.1.1.

Szreter, S. (2005) Health and Wealth: Studies in History and Policy. Rochester, NY: University of Rochester Press.

Szreter, S. and Mooney, G. (1998) Urbanization, mortality and the standard of living debate: new estimates of the expectation of life at birth in nineteenth-century British cities', Economic History Review 51: 84-112. https://doi.org/10.1111/1468-0289.00084.

Tatham, J. (1907). Letter to the Registrar General on the mortality in England and Wales in the period of ten years 1891-1900. In Supplement to the Sixty-Fifth Annual Report of the Registrar

Mortality decline by cause/Text/ 36 
General of Births, Deaths and Marriages in England and Wales 1891-1900 (part I). London: Her Majesty's Stationery Office.

Vaile, M. (2015) Late Victorian Sandwich—polluted water, sickness, council inertia and the case of the deceased unnamed mayor: a public health study, Archaeologia Cantiana 136: 101-15.

Wilson, L.G. (2005) Commentary: medicine, population and tuberculosis, International Journal of Epidemiology 34: 521-4. https://doi.org/10.1093/ije/dyh196.

Wohl, A. (1983) Endangered Lives: Public Health in Victorian Britain. London: Methuen.

Woods, R. (1985) The effects of population redistribution on the level of mortality nineteenthcentury England and Wales, Journal of Economic History 45: 645-51. https://doi.org/10.1017/S0022050700034549.

Woods, R., Watterson, P.A. and Woodward, J. (1988) The causes of rapid infant mortality decline in England and Wales 1861-1921, part I, Population Studies 42: 343-66.

https://doi.org/10.1080/0032472031000143516.

Woods, R. (1997) Causes of Death in England and Wales, 1851-1860 to 1891-1900: the Decennial Supplements [data collection]. UK Data Service. SN: 3552.

http://doi.org/10.5255/UKDA-SN-3552-1.

Woods, R. (2000) The Demography of Victorian England and Wales. Cambridge: Cambridge University Press.

Woods, R. and Shelton, N. (1997) An Atlas of Victorian Mortality. Liverpool, Liverpool University Press.

Mortality decline by cause/Text/ 37 
Table 1

Causes of death used by the Registrar General to report deaths due to potentially water- and food-borne diseases, 1851-1910

\begin{tabular}{|c|c|c|c|c|c|}
\hline $1851-1860$ & $1861-1870$ & $1871-1880$ & $1881-1890$ & $1891-1900$ & 1901-1910 \\
\hline \multirow[t]{3}{*}{ Typhus } & Typhus & Typhus & Typhus & Typhus & Typhus \\
\hline & & Enteric fever & Enteric fever & Enteric fever & Enteric fever \\
\hline & & $\begin{array}{l}\text { Simple } \\
\text { continued } \\
\text { fever }\end{array}$ & $\begin{array}{l}\text { Simple } \\
\text { continued } \\
\text { fever }\end{array}$ & $\begin{array}{l}\text { Simple } \\
\text { continued } \\
\text { fever }\end{array}$ & Pyrexia \\
\hline \multirow[t]{2}{*}{$\begin{array}{l}\text { Cholera, } \\
\text { diarrhoea, } \\
\text { etc. }\end{array}$} & $\begin{array}{l}\text { Diarrhoea } \\
\text { and } \\
\text { dysentery }\end{array}$ & $\begin{array}{l}\text { Diarrhoea } \\
\text { and } \\
\text { dysentery }\end{array}$ & $\begin{array}{l}\text { Diarrhoea } \\
\text { and } \\
\text { dysentery }\end{array}$ & $\begin{array}{l}\text { Diarrhoea } \\
\text { and } \\
\text { dysentery }\end{array}$ & $\begin{array}{l}\text { Diarrhoea } \\
\text { and } \\
\text { dysentery }\end{array}$ \\
\hline & Cholera & Cholera & Cholera & Cholera & \\
\hline $\begin{array}{l}\text { Diseases of } \\
\text { the stomach }\end{array}$ & $\begin{array}{l}\text { Diseases of } \\
\text { the stomach } \\
\text { and liver }\end{array}$ & $\begin{array}{l}\text { Diseases of } \\
\text { the digestive } \\
\text { system }\end{array}$ & $\begin{array}{l}\text { Diseases of } \\
\text { the digestive } \\
\text { system }\end{array}$ & $\begin{array}{l}\text { Diseases of } \\
\text { the digestive } \\
\text { system }\end{array}$ & \\
\hline
\end{tabular}

Sources: Woods (1997) for 1851-1860 to 1891-1900; Registrar General (1919) for 1901-1910.

Mortality decline by cause/Tables/ 1 
Table 2

Causes of death used by the Registrar General to report deaths due to tuberculosis, 1851-1910

\begin{tabular}{|c|c|c|c|c|c|}
\hline $1851-1860$ & $1861-1870$ & $1871-1880$ & 1881-1890 & 1891-1900 & 1901-1910 \\
\hline \multirow[t]{2}{*}{ Phthisis } & Phthisis & Phthisis & Phthisis & Phthisis & $\begin{array}{l}\text { Phthisis (not } \\
\text { otherwise } \\
\text { defined) }\end{array}$ \\
\hline & & & & & $\begin{array}{l}\text { Pulmonary } \\
\text { tuberculosis }\end{array}$ \\
\hline \multirow[t]{4}{*}{$\begin{array}{l}\text { Scrofula, } \\
\text { tabes } \\
\text { mesenterica }\end{array}$} & $\begin{array}{l}\text { Scrofula, } \\
\text { tabes }\end{array}$ & Scrofula & $\begin{array}{l}\text { Other } \\
\text { tuberculosis }\end{array}$ & $\begin{array}{l}\text { Other } \\
\text { tuberculosis }\end{array}$ & $\begin{array}{l}\text { Other } \\
\text { tuberculous } \\
\text { diseases }^{1}\end{array}$ \\
\hline & & & & & $\begin{array}{l}\text { Tuberculous } \\
\text { peritonitis }\end{array}$ \\
\hline & & & & & $\begin{array}{l}\text { Tuberculous } \\
\text { meningitis }\end{array}$ \\
\hline & & $\begin{array}{l}\text { Tabes } \\
\text { mesenterica }\end{array}$ & $\begin{array}{l}\text { Tabes } \\
\text { mesenterica }\end{array}$ & $\begin{array}{l}\text { Tabes } \\
\text { mesenterica }\end{array}$ & $\begin{array}{l}\text { Tabes } \\
\text { mesenterica }\end{array}$ \\
\hline
\end{tabular}

1. These included 'lupus', 'tubercle of other organs', 'general tuberculosis', 'scrofula'.

Sources: Woods (1997) for 1851-1860 to 1891-1900; Registrar General (1919) for 1901-1910.

Mortality decline by cause/Tables/ 2 
Table 3

Contribution of different causes of death to change in expectation of life at birth, England and Wales 1851-1910 ${ }^{1}$

\begin{tabular}{|c|c|c|c|c|c|}
\hline Cause of death & $\begin{array}{l}1851-1860 \\
\text { to } \\
1861-1870\end{array}$ & $\begin{array}{l}1861-1870 \\
\text { to } \\
1871-1880\end{array}$ & $\begin{array}{l}1871-1880 \\
\text { to } \\
1881-1890\end{array}$ & $\begin{array}{l}1881-1890 \\
\text { to } \\
1891-1900\end{array}$ & $\begin{array}{l}1891-1900 \\
\text { to } \\
1901-1910\end{array}$ \\
\hline Smallpox & 0.09 & -0.10 & 0.28 & 0.05 & 0.00 \\
\hline Measles & -0.03 & 0.09 & -0.13 & -0.21 & 0.16 \\
\hline Scarlet fever & -0.12 & 0.39 & 0.57 & 0.26 & 0.09 \\
\hline Diphtheria & -0.11 & 0.09 & -0.07 & -0.22 & 0.13 \\
\hline Whooping cough & -0.02 & 0.02 & 0.05 & 0.07 & 0.15 \\
\hline $\begin{array}{l}\text { Typhus, typhoid, cholera, } \\
\text { diarrhoea and dysentery }\end{array}$ & 0.03 & 0.66 & 0.65 & -0.13 & 0.35 \\
\hline Cancer & -0.06 & -0.07 & -0.10 & -0.13 & -0.08 \\
\hline Other tuberculosis & -0.04 & -0.02 & -0.43 & 0.07 & 0.20 \\
\hline $\begin{array}{l}\text { Pulmonary tuberculosis } \\
\text { (phthisis) }\end{array}$ & 0.25 & 0.47 & 0.57 & 0.54 & 0.42 \\
\hline Diseases of the lungs ${ }^{3}$ & -0.27 & -0.42 & -0.19 & 0.33 & 1.13 \\
\hline Childbirth & -0.01 & -0.01 & 0.02 & 0.02 & 0.07 \\
\hline Violence & -0.03 & 0.06 & 0.11 & -0.03 & 0.14 \\
\hline Other causes & 0.30 & 0.45 & 1.02 & 0.19 & 1.54 \\
\hline $\begin{array}{l}\text { Increase in expectation of life } \\
\text { at birth }\end{array}$ & -0.02 & 1.61 & 2.35 & 0.81 & 4.30 \\
\hline
\end{tabular}

Mortality decline by cause/Tables/ 3 
1. The figures in this table are all given as the additional years of life supplied by changes in mortality from the relevant cause. They are for males and females combined.

2. Following Woods (2000), we have combined 'typhus and typhoid' and 'cholera, diarrhoea and dysentery' into a single category, as it makes the temporal pattern simpler to interpret.

3. 'Diseases of the lungs' in 1851-1860 to 1891-1900 include deaths so described by the Registrar General; in 1901-1910 'diseases of the lungs' include deaths described by the Registrar General as being from 'influenza', 'bronchitis' and 'pneumonia'.

Sources: Woods (1997) for 1851-1860 to 1891-1900; Registrar General (1919) for 1901-1910. For method of calculation see Beltrán-Sánchez et al. (2008). 
Table 4

Death rates from five causes of death in England and Wales in 1851-1860 and each subsequent decade until 1901-1910: areas grouped by population density per acre ${ }^{1}$

\begin{tabular}{|c|c|c|c|c|c|c|c|c|c|c|c|c|c|c|}
\hline \multirow[b]{2}{*}{$\begin{array}{l}\text { Cause of death } \\
\text { and decade }\end{array}$} & \multicolumn{7}{|c|}{$\begin{array}{l}\text { Death rate per thousand by population density per acre } \\
\qquad(d)\end{array}$} & \multicolumn{7}{|c|}{$\begin{array}{l}\text { Death rate per thousand relative to } 1861-1870(=100) \text { by } \\
\text { population density per acre }(d)\end{array}$} \\
\hline & $\begin{array}{c}\text { All } \\
\text { areas }\end{array}$ & $\begin{array}{l}d< \\
1.0\end{array}$ & $\begin{array}{l}d \geq \\
1.0\end{array}$ & $\begin{array}{c}1.0 \leq \\
d< \\
3.0\end{array}$ & $\begin{array}{c}3.0 \leq \\
d< \\
10.0\end{array}$ & $\begin{array}{c}d \geq \\
10.0 \\
\text { excl. } \\
\text { Lon- } \\
\text { don }\end{array}$ & $\begin{array}{l}\text { Lon- } \\
\text { don }\end{array}$ & $\begin{array}{c}\text { All } \\
\text { areas }\end{array}$ & $\begin{array}{l}d< \\
1.0\end{array}$ & $\begin{array}{l}d \geq \\
1.0\end{array}$ & $\begin{array}{c}1.0 \leq \\
d< \\
3.0\end{array}$ & $\begin{array}{c}3.0 \leq \\
d< \\
10.0\end{array}$ & $\begin{array}{c}d \geq \\
10.0 \\
\text { excl. } \\
\text { Lon- } \\
\text { don }\end{array}$ & $\begin{array}{l}\text { Lon- } \\
\text { don }\end{array}$ \\
\hline \multicolumn{15}{|c|}{ Diarrhoeal diseases } \\
\hline $1851-1860$ & 1.08 & 0.61 & 1.51 & 1.08 & 1.43 & 2.00 & 1.53 & 100 & 95 & 106 & 95 & 104 & 104 & 118 \\
\hline $1861-1870$ & 1.08 & 0.64 & 1.42 & 1.14 & 1.38 & 1.92 & 1.30 & 100 & 100 & 100 & 100 & 100 & 100 & 100 \\
\hline $1871-1880$ & 0.94 & 0.58 & 1.18 & 1.07 & 1.18 & 1.54 & 0.98 & 87 & 91 & 83 & 94 & 86 & 80 & 75 \\
\hline $1881-1890$ & 0.67 & 0.40 & 0.84 & 0.77 & 0.81 & 1.05 & 0.78 & 62 & 63 & 59 & 68 & 59 & 55 & 60 \\
\hline $1891-1900$ & 0.73 & 0.43 & 0.91 & 0.84 & 0.90 & 1.14 & 0.78 & 68 & 67 & 64 & 74 & 65 & 59 & 60 \\
\hline $1901-1910$ & 0.57 & 0.30 & 0.71 & 0.67 & 0.66 & 0.89 & 0.65 & 53 & 47 & 50 & 59 & 48 & 46 & 50 \\
\hline \multicolumn{15}{|c|}{ Typhus and typhoid } \\
\hline $1851-1860$ & 0.91 & 0.86 & 0.95 & 0.92 & 0.95 & 1.09 & 0.85 & 103 & 118 & 94 & 101 & 95 & 87 & 96 \\
\hline $1861-1870$ & 0.88 & 0.73 & 1.01 & 0.91 & 1.00 & 1.26 & 0.89 & 100 & 100 & 100 & 100 & 100 & 100 & 100 \\
\hline $1871-1880$ & 0.48 & 0.41 & 0.54 & 0.60 & 0.55 & 0.63 & 0.37 & 55 & 56 & 53 & 66 & 55 & 50 & 42 \\
\hline $1881-1890$ & 0.24 & 0.19 & 0.27 & 0.29 & 0.25 & 0.33 & 0.21 & 27 & 26 & 27 & 32 & 25 & 26 & 24 \\
\hline $1891-1900$ & 0.18 & 0.13 & 0.21 & 0.22 & 0.21 & 0.25 & 0.15 & 20 & 18 & 21 & 24 & 21 & 20 & 17 \\
\hline $1901-1910$ & 0.09 & 0.07 & 0.10 & 0.11 & 0.10 & 0.12 & 0.07 & 10 & 10 & 10 & 12 & 10 & 10 & 8 \\
\hline \multicolumn{15}{|c|}{ Diarrhoeal diseases, typhus and typhoid } \\
\hline $1851-1860$ & 1.99 & 1.47 & 2.46 & 2.01 & 2.38 & 3.09 & 2.38 & 102 & 107 & 101 & 98 & 100 & 97 & 109 \\
\hline $1861-1870$ & 1.96 & 1.37 & 2.44 & 2.05 & 2.38 & 3.17 & 2.19 & 100 & 100 & 100 & 100 & 100 & 100 & 100 \\
\hline $1871-1880$ & 1.42 & 1.00 & 1.72 & 1.67 & 1.73 & 2.17 & 1.36 & 72 & 73 & 70 & 81 & 73 & 68 & 62 \\
\hline $1881-1890$ & 0.91 & 0.59 & 1.11 & 1.06 & 1.06 & 1.37 & 0.99 & 46 & 43 & 45 & 52 & 45 & 43 & 45 \\
\hline $1891-1900$ & 0.92 & 0.56 & 1.12 & 1.07 & 1.11 & 1.39 & 0.93 & 47 & 41 & 46 & 52 & 47 & 44 & 42 \\
\hline
\end{tabular}

Mortality decline by cause/Tables/ 5 


\begin{tabular}{|c|c|c|c|c|c|c|c|c|c|c|c|c|c|c|}
\hline 1901-1910 & 0.66 & 0.37 & 0.82 & 0.79 & 0.77 & 1.01 & 0.71 & 34 & 27 & 34 & 39 & 32 & 32 & 32 \\
\hline \multicolumn{15}{|l|}{ Scarlet fever } \\
\hline $1851-1860$ & 0.88 & 0.69 & 1.05 & 0.96 & 1.09 & 1.18 & 0.94 & 91 & 99 & 88 & 83 & 89 & 94 & 82 \\
\hline 1861-1870 & 0.97 & 0.70 & 1.19 & 1.15 & 1.22 & 1.25 & 1.14 & 100 & 100 & 100 & 100 & 100 & 100 & 100 \\
\hline $1871-1880$ & 0.71 & 0.50 & 0.86 & 0.90 & 0.97 & 0.97 & 0.61 & 73 & 71 & 72 & 78 & 80 & 78 & 54 \\
\hline $1881-1890$ & 0.33 & 0.23 & 0.40 & 0.42 & 0.39 & 0.46 & 0.33 & 34 & 33 & 34 & 37 & 32 & 37 & 29 \\
\hline $1891-1900$ & 0.16 & 0.11 & 0.19 & 0.19 & 0.19 & 0.19 & 0.17 & 16 & 16 & 16 & 17 & 16 & 15 & 15 \\
\hline 1901-1910 & 0.11 & 0.07 & 0.12 & 0.11 & 0.16 & 0.13 & 0.08 & 11 & 10 & 10 & 10 & 13 & 10 & 7 \\
\hline \multicolumn{15}{|c|}{ Phthisis (pulmonary tuberculosis) } \\
\hline $1851-1860$ & 2.68 & 2.51 & 2.83 & 2.65 & 2.72 & 3.07 & 2.89 & 108 & 110 & 108 & 112 & 112 & 105 & 98 \\
\hline 1861-1870 & 2.48 & 2.28 & 2.63 & 2.37 & 2.43 & 2.91 & 2.86 & 100 & 100 & 100 & 100 & 100 & 100 & 100 \\
\hline $1871-1880$ & 2.12 & 1.91 & 2.26 & 1.98 & 2.06 & 2.53 & 2.53 & 85 & 84 & 86 & 84 & 85 & 87 & 88 \\
\hline $1881-1890$ & 1.72 & 1.54 & 1.84 & 1.63 & 1.66 & 2.06 & 2.10 & 69 & 68 & 70 & 69 & 68 & 71 & 73 \\
\hline $1891-1900$ & 1.39 & 1.19 & 1.50 & 1.31 & 1.31 & 1.69 & 1.81 & 56 & 52 & 57 & 55 & 54 & 58 & 63 \\
\hline 1901-1910 & 1.16 & 1.00 & 1.25 & 1.09 & 1.10 & 1.44 & 1.50 & 47 & 44 & 48 & 46 & 45 & 49 & 52 \\
\hline \multicolumn{15}{|c|}{ Diseases of the lungs ${ }^{3}$} \\
\hline $1851-1860$ & 3.02 & 2.29 & 3.69 & 2.91 & 3.44 & 4.27 & 4.08 & 90 & 88 & 92 & 90 & 90 & 93 & 94 \\
\hline $1861-1870$ & 3.36 & 2.60 & 3.99 & 3.23 & 3.83 & 4.57 & 4.32 & 100 & 100 & 100 & 100 & 100 & 100 & 100 \\
\hline $1871-1880$ & 3.76 & 3.02 & 4.28 & 3.62 & 4.16 & 4.73 & 4.65 & 112 & 116 & 107 & 112 & 109 & 104 & 108 \\
\hline $1881-1890$ & 3.73 & 3.02 & 4.17 & 3.73 & 4.03 & 4.69 & 4.33 & 111 & 116 & 105 & 115 & 105 & 103 & 100 \\
\hline $1891-1900$ & 3.41 & 2.74 & 3.79 & 3.44 & 3.65 & 4.19 & 3.96 & 101 & 105 & 95 & 107 & 95 & 92 & 92 \\
\hline $1901-1910$ & 2.64 & 2.19 & 2.88 & 2.69 & 2.71 & 3.23 & 3.03 & 79 & 84 & 72 & 83 & 71 & 71 & 70 \\
\hline $\begin{array}{l}\text { Number of } \\
\text { areas }\end{array}$ & 588 & 445 & 143 & 50 & 43 & 25 & 25 & & & & & & & \\
\hline $\begin{array}{l}\text { Percentage of } \\
\text { England and }\end{array}$ & & & & & & & & & & & & & & \\
\hline $\begin{array}{l}\text { Wales } \\
\text { population in } \\
1880 \text { s }\end{array}$ & 100.0 & 38.5 & 61.5 & 14.3 & 19.4 & 13.5 & 14.3 & & & & & & & \\
\hline
\end{tabular}

Mortality decline by cause/Tables/ 6 
1. The death rates in this table were calculated for each decade by summing the total number of deaths recorded in registration areas within each population density category and dividing the total number of deaths by the total population living in all registration areas within each population density category.

2. 'London' includes all registration districts in the registration county of London except for Lewisham, which had a population density of under 10 persons per acre in 1881. Rather than add extra columns to the table, Lewisham has been retained within the category of 3-10 persons per acre.

3. 'Diseases of the lungs' in 1851-1860 to 1891-1900 include deaths so described by the Registrar General; in 1901-1910 'diseases of the lungs' include deaths described by the Registrar General as being from 'influenza', 'bronchitis' and 'pneumonia'.

Sources: Woods (1997) for 1851-1860 to 1891-1900; Registrar General (1919) for 1901-1910. See Gatley (1997) for information on acreage of areas, and proportion of adult males in mining in 1861 . 
Table 5

Death rates from five causes in England and Wales in 1851-1860 and each subsequent decade until 1901-1910: areas grouped by percentage of the population living in urban settlements with more than 10,000 inhabitants $^{1}$

\begin{tabular}{|c|c|c|c|c|c|c|c|c|c|c|c|c|c|c|}
\hline \multirow[b]{2}{*}{$\begin{array}{l}\text { Cause of death } \\
\text { and decade }\end{array}$} & \multicolumn{7}{|c|}{$\begin{array}{l}\text { Death rate per thousand by percentage living in towns } \\
\text { with a population greater than } 10,000(g)\end{array}$} & \multicolumn{7}{|c|}{$\begin{array}{l}\text { Death rate per thousand relative to } 1861-1870(=100) \text { by } \\
\text { percentage living in towns with a population greater than } \\
\qquad 10,000(\mathrm{~g})\end{array}$} \\
\hline & $\begin{array}{c}\text { All } \\
\text { areas }\end{array}$ & $g=0$ & $g>0$ & $\begin{array}{l}0<g \\
<60\end{array}$ & $\begin{array}{r}60 \leq g \\
<90\end{array}$ & $\begin{array}{l}g \geq 90 \\
\text { excl. } \\
\text { Lon- } \\
\text { don }\end{array}$ & $\begin{array}{l}\text { Lon- } \\
\text { don }\end{array}$ & $\begin{array}{l}\text { All } \\
\text { areas }\end{array}$ & $g=0$ & $g>0$ & $\begin{array}{l}0<g \\
<60\end{array}$ & $\begin{array}{c}60 \leq \\
g< \\
90\end{array}$ & $\begin{array}{l}g \geq 90 \\
\text { excl. } \\
\text { Lon- } \\
\text { don }\end{array}$ & $\begin{array}{l}\text { Lon- } \\
\text { don }\end{array}$ \\
\hline \multicolumn{15}{|c|}{ Diarrhoeal diseases } \\
\hline $1851-1860$ & 1.08 & 0.57 & 1.33 & 0.75 & 1.41 & 1.82 & 1.53 & 100 & 98 & 103 & 86 & 106 & 103 & 118 \\
\hline $1861-1870$ & 1.08 & 0.58 & 1.29 & 0.87 & 1.33 & 1.77 & 1.30 & 100 & 100 & 100 & 100 & 100 & 100 & 100 \\
\hline $1871-1880$ & 0.94 & 0.52 & 1.09 & 0.79 & 1.19 & 1.41 & 0.98 & 87 & 90 & 84 & 91 & 89 & 80 & 75 \\
\hline $1881-1890$ & 0.67 & 0.36 & 0.78 & 0.56 & 0.81 & 0.99 & 0.78 & 62 & 62 & 60 & 64 & 61 & 56 & 60 \\
\hline $1891-1900$ & 0.73 & 0.38 & 0.85 & 0.62 & 0.88 & 1.10 & 0.78 & 68 & 66 & 66 & 71 & 66 & 62 & 60 \\
\hline $1901-1910$ & 0.57 & 0.27 & 0.65 & 0.48 & 0.65 & 0.85 & 0.65 & 53 & 47 & 50 & 55 & 49 & 48 & 50 \\
\hline \multicolumn{15}{|c|}{ Typhus and typhoid } \\
\hline $1851-1860$ & 0.91 & 0.83 & 0.94 & 0.88 & 1.00 & 1.03 & 0.85 & 103 & 124 & 96 & 102 & 103 & 87 & 96 \\
\hline $1861-1870$ & 0.88 & 0.67 & 0.98 & 0.86 & 0.97 & 1.19 & 0.89 & 100 & 100 & 100 & 100 & 100 & 100 & 100 \\
\hline $1871-1880$ & 0.48 & 0.38 & 0.52 & 0.50 & 0.60 & 0.57 & 0.37 & 55 & 57 & 53 & 58 & 62 & 48 & 42 \\
\hline $1881-1890$ & 0.24 & 0.17 & 0.26 & 0.23 & 0.28 & 0.29 & 0.21 & 27 & 25 & 27 & 27 & 29 & 24 & 24 \\
\hline $1891-1900$ & 0.18 & 0.11 & 0.20 & 0.19 & 0.22 & 0.24 & 0.15 & 20 & 16 & 20 & 22 & 23 & 20 & 17 \\
\hline $1901-1910$ & 0.09 & 0.06 & 0.10 & 0.11 & 0.11 & 0.10 & 0.07 & 10 & 9 & 10 & 13 & 11 & 8 & 8 \\
\hline \multicolumn{15}{|c|}{ Diarrhoeal diseases, typhus and typhoid } \\
\hline $1851-1860$ & 1.99 & 1.40 & 2.27 & 1.63 & 2.41 & 2.85 & 2.38 & 102 & 111 & 100 & 94 & 105 & 96 & 109 \\
\hline $1861-1870$ & 1.96 & 1.26 & 2.26 & 1.73 & 2.30 & 2.96 & 2.19 & 100 & 100 & 100 & 100 & 100 & 100 & 100 \\
\hline $1871-1880$ & 1.42 & 0.91 & 1.61 & 1.29 & 1.79 & 1.99 & 1.36 & 72 & 72 & 71 & 75 & 78 & 67 & 62 \\
\hline $1881-1890$ & 0.91 & 0.53 & 1.04 & 0.79 & 1.10 & 1.27 & 0.99 & 46 & 42 & 46 & 46 & 48 & 43 & 45 \\
\hline
\end{tabular}

Mortality decline by cause/Tables/ 8 


\begin{tabular}{|c|c|c|c|c|c|c|c|c|c|c|c|c|c|c|}
\hline 1891-1900 & 0.92 & 0.49 & 1.05 & 0.81 & 1.10 & 1.34 & 0.93 & 47 & 39 & 46 & 47 & 48 & 45 & 42 \\
\hline $1901-1910$ & 0.66 & 0.33 & 0.76 & 0.59 & 0.77 & 0.95 & 0.71 & 33 & 23 & 33 & 36 & 32 & 32 & 32 \\
\hline \multicolumn{15}{|l|}{ Scarlet fever } \\
\hline $1851-1860$ & 0.88 & 0.64 & 0.99 & 0.87 & 1.06 & 1.11 & 0.94 & 91 & 100 & 88 & 94 & 87 & 94 & 82 \\
\hline $1861-1870$ & 0.97 & 0.64 & 1.12 & 0.93 & 1.22 & 1.18 & 1.14 & 100 & 100 & 100 & 100 & 100 & 100 & 100 \\
\hline $1871-1880$ & 0.71 & 0.44 & 0.82 & 0.75 & 0.98 & 0.87 & 0.61 & 73 & 69 & 73 & 81 & 80 & 74 & 54 \\
\hline $1881-1890$ & 0.33 & 0.20 & 0.39 & 0.33 & 0.42 & 0.42 & 0.33 & 34 & 31 & 35 & 35 & 34 & 36 & 29 \\
\hline $1891-1900$ & 0.16 & 0.09 & 0.18 & 0.16 & 0.18 & 0.20 & 0.17 & 16 & 14 & 16 & 17 & 15 & 17 & 15 \\
\hline 1901-1910 & 0.11 & 0.06 & 0.12 & 0.10 & 0.12 & 0.16 & 0.08 & 11 & 9 & 11 & 11 & 10 & 14 & 7 \\
\hline \multicolumn{15}{|c|}{ Phthisis (pulmonary tuberculosis) } \\
\hline $1851-1860$ & 2.68 & 2.44 & 2.79 & 2.61 & 2.80 & 2.92 & 2.89 & 108 & 110 & 108 & 111 & 111 & 107 & 98 \\
\hline $1861-1870$ & 2.48 & 2.21 & 2.59 & 2.35 & 2.52 & 2.74 & 2.86 & 100 & 100 & 100 & 100 & 100 & 100 & 100 \\
\hline $1871-1880$ & 2.12 & 1.84 & 2.22 & 1.99 & 2.13 & 2.35 & 2.53 & 85 & 83 & 86 & 85 & 85 & 86 & 88 \\
\hline $1881-1890$ & 1.72 & 1.49 & 1.80 & 1.58 & 1.75 & 1.88 & 2.10 & 69 & 67 & 69 & 67 & 69 & 69 & 73 \\
\hline $1891-1900$ & 1.39 & 1.15 & 1.46 & 1.22 & 1.44 & 1.50 & 1.81 & 56 & 52 & 56 & 52 & 57 & 55 & 63 \\
\hline 1901-1910 & 1.16 & 0.98 & 1.22 & 1.01 & 1.19 & 1.29 & 1.50 & 47 & 44 & 47 & 43 & 47 & 47 & 52 \\
\hline \multicolumn{15}{|c|}{ Diseases of the lungs ${ }^{3}$} \\
\hline $1851-1860$ & 3.02 & 2.23 & 3.39 & 2.52 & 3.36 & 4.02 & 4.08 & 90 & 90 & 91 & 87 & 89 & 95 & 94 \\
\hline $1861-1870$ & 3.36 & 2.49 & 3.74 & 2.90 & 3.78 & 4.23 & 4.32 & 100 & 100 & 100 & 100 & 100 & 100 & 100 \\
\hline $1871-1880$ & 3.76 & 2.86 & 4.09 & 3.40 & 4.11 & 4.44 & 4.65 & 112 & 115 & 109 & 117 & 109 & 105 & 108 \\
\hline $1881-1890$ & 3.73 & 2.86 & 4.02 & 3.35 & 4.16 & 4.35 & 4.33 & 111 & 115 & 107 & 116 & 110 & 103 & 100 \\
\hline $1891-1900$ & 3.41 & 2.56 & 3.66 & 3.10 & 3.77 & 3.92 & 3.96 & 101 & 103 & 98 & 107 & 100 & 93 & 92 \\
\hline 1901-1910 & 2.64 & 2.08 & 2.80 & 2.43 & 2.88 & 2.97 & 3.03 & 79 & 84 & 75 & 84 & 76 & 70 & 70 \\
\hline $\begin{array}{l}\text { Number of } \\
\text { areas }\end{array}$ & 588 & 361 & 227 & 105 & 59 & 38 & 25 & & & & & & & \\
\hline \multicolumn{15}{|l|}{$\begin{array}{l}\text { Percentage of } \\
\text { England and }\end{array}$} \\
\hline $\begin{array}{l}\text { Wales } \\
\text { population in } \\
1880 \text { s }\end{array}$ & 100.0 & 24.9 & 75.1 & 20.3 & 23.3 & 17.4 & 14.3 & & & & & & & \\
\hline
\end{tabular}

Mortality decline by cause/Tables/ 9 
1. The death rates in this table were calculated for each decade by summing the total number of deaths recorded in registration areas within each population density category and dividing the total number of deaths by the total population living in all registration areas within each population density category.

2. 'London' includes all registration districts in the registration county of London except for Lewisham, which had a population density of under 10 persons per acre in 1881. Rather than add extra columns to the table, Lewisham has been retained within the category of 3-10 persons per acre.

3. 'Diseases of the lungs' in 1851-1860 to 1891-1900 include deaths so described by the Registrar General; in 1901-1910 'diseases of the lungs' include deaths described by the Registrar General as being from 'influenza', 'bronchitis' and 'pneumonia'.

Sources: Woods (1997) for 1851-1860 to 1891-1900; Registrar General (1919) for 1901-1910. See Gatley (1997) for information on acreage of areas, and proportion of adult males in mining in 1861 . 
Table 6

Percentage contributions of different causes of death to change in mortality, England and Wales $1851-1910^{1}$

\begin{tabular}{|c|c|c|c|}
\hline \multirow[t]{2}{*}{ Cause of death } & \multicolumn{2}{|c|}{$\begin{array}{l}1861-1870 \text { to } 1891- \\
1900\end{array}$} & \multirow{2}{*}{$\begin{array}{l}1851-1860 \\
\text { to } \\
1901-1910 \\
\text { Our } \\
\text { estimates }\end{array}$} \\
\hline & $\begin{array}{l}\text { Woods } \\
(2000)\end{array}$ & $\begin{array}{l}\text { Our } \\
\text { estimates }\end{array}$ & \\
\hline Smallpox & 4.3 & 4.8 & 3.5 \\
\hline Measles & -0.7 & -5.2 & -1.3 \\
\hline Scarlet fever & 22.5 & 25.6 & 13.2 \\
\hline Diphtheria & -2.8 & -4.2 & -2.0 \\
\hline Whooping cough & -2.5 & 2.9 & 3.0 \\
\hline $\begin{array}{l}\text { Typhus, typhoid, cholera, } \\
\text { diarrhoea and dysentery }{ }^{1}\end{array}$ & 28.1 & 24.7 & 17.2 \\
\hline Cancer & -11.3 & -6.3 & -4.9 \\
\hline Other tuberculosis ${ }^{2}$ & -6.8 & -8.0 & -2.4 \\
\hline $\begin{array}{l}\text { Pulmonary tuberculosis } \\
\text { (phthisis) }\end{array}$ & 35.2 & 33.1 & 24.9 \\
\hline Diseases of the lungs ${ }^{3}$ & -7.3 & -5.9 & 6.4 \\
\hline Childbirth & 0.6 & 0.6 & 1.0 \\
\hline Violence & 8.1 & 2.9 & 2.8 \\
\hline Other causes & 32.6 & 34.8 & 38.7 \\
\hline $\begin{array}{l}\text { Increase in expectation of life } \\
\text { at birth (years) }\end{array}$ & & 4.77 & 9.05 \\
\hline
\end{tabular}

Mortality decline by cause/Tables/ 11 
1. Following Woods (2000), we have combined 'typhus and typhoid' and 'cholera, diarrhoea and dysentery' into a single category, as it makes the temporal pattern simpler to interpret. Negative numbers mean that mortality from that cause of death increased in absolute terms.

2. We have equated our category of 'other tuberculosis' to Woods's category of 'scrofula'.

3. 'Diseases of the lungs' in 1851-1860 to 1891-1900 include deaths so described by the Registrar General; in 1901-1910 'diseases of the lungs' include deaths described by the Registrar General as being from 'influenza', 'bronchitis' and 'pneumonia'.

Sources: Woods (2000, pp. 350-1), Woods (1997) for 1851-1860 to 1891-1900; Registrar General (1919) for 1901-1910. For method of calculation of our estimates see Beltrán-Sánchez et al. (2008). 
Figure 1

Loans for public works sanctioned by the Local Government Board to urban and rural sanitary authorities in England and Wales, 1873-97 ( $£$ per thousand inhabitants) ${ }^{1}$

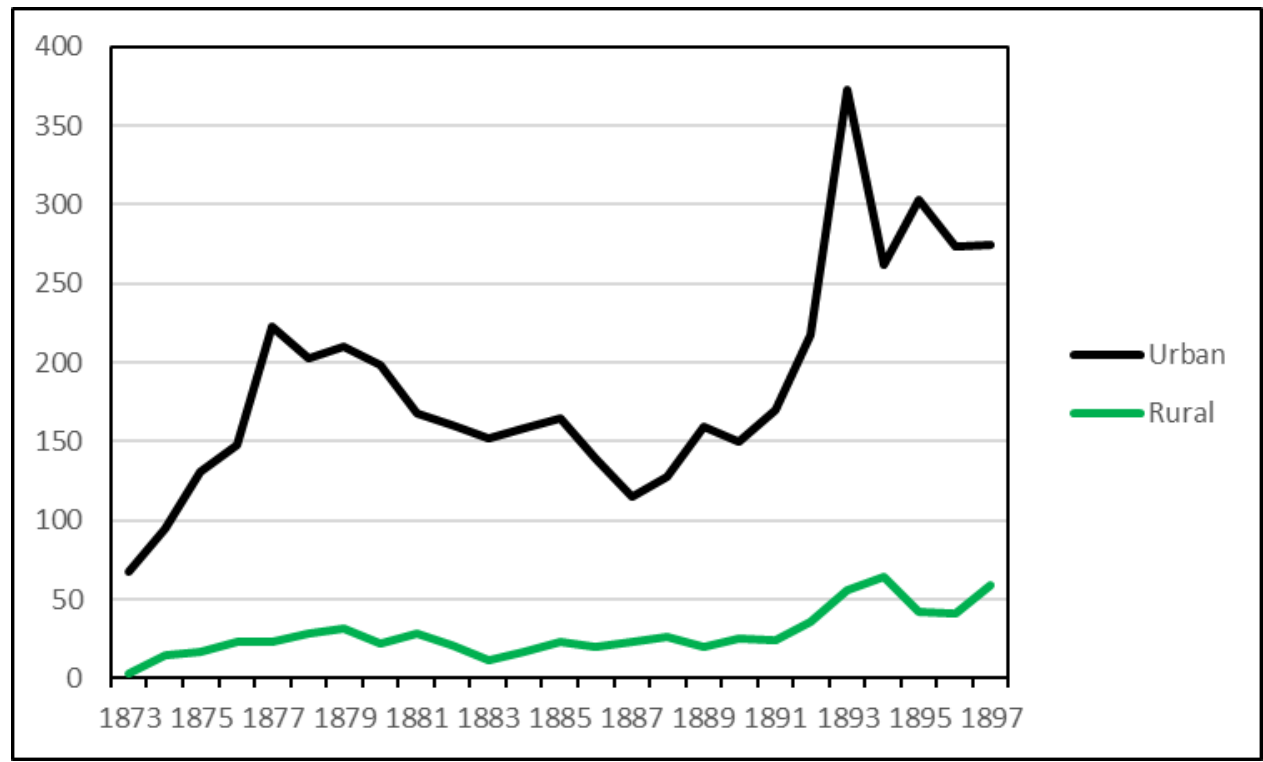

1. 'Rural' areas are those with rural sanitary authorities, 'urban' areas are those with urban sanitary authorities. Prices are in current values.

Sources: loans data from Harris and Hinde (2019, p. 5). Populations estimated from census data using linear interpolation between censuses.

Mortality decline by cause/Figures/ 1 